\title{
Post-earthquake quality of life among students
}

\author{
Rusmini $^{1}$, Lale Wisnu Andrayani ${ }^{2}$, Hamdan Hariawan ${ }^{3}$ \\ ${ }^{1,2}$ Poltekkes Kemenkes Mataram, Indonesia \\ ${ }^{3}$ Poltekkes Kemenkes Maluku, Indonesia
}

\begin{tabular}{|c|c|}
\hline Article Info & ABSTRACT \\
\hline Article history: & \multirow{8}{*}{$\begin{array}{l}\text { Quality of life is one of the many psychological impacts of post-disaster. } \\
\text { One of the impacts of the North Lombok earthquake in } 2018 \text { was that many } \\
\text { school buildings and residences were damaged and collapsed. This research } \\
\text { aimed to determine the quality of life of boarders and public students } \\
\text { displaced after the earthquake in North Lombok. This research was } \\
\text { comparative research with cross-sectional design. The samples of this } \\
\text { research were } 85 \text { students consist of } 40 \text { students of emergency public school } \\
\text { and } 45 \text { students of emergency Islamic boarding school. This research } \\
\text { variable was the quality of life of boarders and public students. } \\
\text { Measurement of this study using KIDSCREEN- } 27 \text { and analyzed by bivariate } \\
\text { and multivariate analysis with the value of } \alpha<0.05 \text {. This study showed } \\
\text { the quality of life for boarders students higher than public students }(\mathrm{p}=0.008) \text {. }\end{array}$} \\
\hline Received Oct 27, 2019 & \\
\hline Revised Jan 28, 2020 & \\
\hline Accepted Apr 23, 2020 & \\
\hline Keywords: & \\
\hline Earthquake & \\
\hline Quality of life & \\
\hline Student & \\
\hline
\end{tabular}

This is an open access article under the CC BY-SA license.

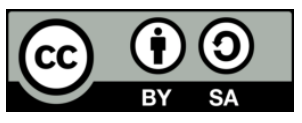

Corresponding Author:

Hamdan Hariawan,

Poltekkes Kemenkes Maluku,

Jalan Laksdya Leo Wattimena, Negeri Lama, Nania, Baguala, Maluku, Indonesia.

Email: hamdan@poltekkes-maluku.ac.id

\section{INTRODUCTION}

One of the recent disasters was the earthquake in Lombok Island with three high-scales of the earthquakes that were 6.4 M on July 29, 2018, 7.0 M on August 9, 2018, and 6.2 M on August 19, 2018. The earthquake series consisted of a Pre shock earthquake, mainshock, and aftershock with the number of earthquakes that occurred almost 500 earthquakes until August 10, 2018. The earthquake gave the impact of 1,033 injury people and 270,168 displaced people. The earthquake also resulted in damage to 67,875 people's homes [1]. In addition to physical impacts, the Lombok earthquake also gave psychic impacts Lombok society. Psychic problems due to Lombok earthquake are the fear of aftershock earthquake, difficulties in forgetting the earthquake, anxiety, anxiety thinking of the earthquake, fears to enter the house, and hear a roaring sound or fear when Night. The Lombok earthquake also raises the symptoms of post traumatic stress disorder (PTSD) which can lead to a quality of life as much as $64.7 \%$ of the 88 respondents studied by the Faculty of Nursing Universitas Diponegoro [2]. Quality of life is one of the psychic impacts after the disaster [3-5]. Some research mentioned that quality of life as the impact of homelessness, disability, loss of family members and socio-economic conditions. The post-disaster quality of life of children to adults is also influenced by changes in daily activities and experiences affecting mental symptoms, such as the symptoms of PTSD. However, this will improve by the development of their adaptation and the length of time after the disaster [6-9].

The other impact of Lombok earthquakes was many school buildings are damaged and collapsed. There were 458 school buildings were damaged after the earthquake, including boarding school where students live and learn [1]. One of the Indonesia government's efforts was to build an emergency school as a place to study and stay while for students [10]. The results of some research mentioned that displaced as a disaster impact could affect the quality of life of a community [11]. In addition, the quality of life of students living 
in dormitories (boarders students) is also different compared to the students who live with their parents at home (public students) $[12,13]$. Therefore, the aim of this research is to determine the quality of life of boarders and public students displaced after the earthquake in North Lombok, Indonesia.

\section{RESEARCH METHOD}

This research was comparative research using a cross-sectional design. The subject of this study was students in public schools as public students and students in Islamic boarding school as boarder's students in North Lombok Regency. The inclusion criteria were students who are 15-18 years old, living in the post-earthquake disaster area, and studying at emergency school or emergency Islamic boarding school. Samples were 85 students consist of 40 students of emergency public school and 45 students of emergency Islamic boarding school. Measurement of quality of life using KIDSCREEN-27. This instrument has five dimensions, namely physical welfare, psychological welfare, relationship with parents and independence, social and peer support, and school environment. KIDSCREEN-27 has 27 items. Quality of life was categorized as good if $\mathrm{T}$ score>mean $\mathrm{T}$, then Quality of life was categorized as poor if $\mathrm{T}$ score<mean $\mathrm{T}[14,15]$. The KIDSCREEN-27 has been adapted and $\alpha=0.880$ [16]. This study analyzed by bivariate and multivariate analysis with $\alpha<0.05$. This research has obtained ethical approval from the Ethics Commission of the Health Research Department of Poltekkes Kemenkes Mataram Number LB. 01.03/1.1/3086/2019.

\section{RESULTS AND DISCUSSION}

Table 1 shows the characteristics of respondents based on gender that most of the boarder's students were women $(66.7 \%)$, while public students were males $(60 \%)$. The characteristics of respondents based on age that most of the boarders students were 19 years old and most of public students were 17 years old. This research shows the difference in the quality of life in public students at public schools with boarder's students at Islamic boarding schools in North Lombok after an earthquake. Students at the upper secondary level are categorized as adolescent-age communities. Adolescents are an easy and vulnerable group of mental health problems after a disaster $[17,18]$. Natural disasters have a negative psychic impact that teenagers are characterized by an increase in the symptoms associated with depression and thoughts on the disaster that has occurred will always harm them. Several recent studies have mentioned natural disasters associated with increased depressive events, anxiety disorders, PTSD, especially in children and adolescents. Earthquake natural disasters also increase PTSD figures in adolescents who become mediators of the declining quality of life of teenagers [19].

Table 1. Respondent characteristics

\begin{tabular}{lcccc}
\hline \multirow{2}{*}{ Respondent characteristics } & \multicolumn{2}{c}{ Boarders students } & \multicolumn{2}{c}{ Public students } \\
& $\mathrm{N}$ & $\%$ & $\mathrm{~N}$ & $\%$ \\
\hline Gender & & & & \\
Male & 15 & 33.3 & 24 & 60 \\
Female & 30 & 66.7 & 16 & 40 \\
Total & 45 & 100 & 40 & 100 \\
Age & & & & \\
15 years old & 15 & 33.3 & 12 & 5 \\
16 years old & 19 & 42.2 & 5 & 12.5 \\
17 years old & 11 & 24.5 & 16 & 40 \\
18 years old & 0 & 0.0 & 15 & 37.5 \\
19 years old & 0 & 0.0 & 2 & 5 \\
Total & 45 & 100 & 40 & 100 \\
\hline
\end{tabular}

PTSD is a traumatic or stressful condition that may develop after exposure to traumatic events such as sexual violence, accidents, and life-threatening disasters. Currently, natural disasters are the most common cause of PTSD cases, such as earthquake disasters. Earthquakes can occur at any time and without warning so that people do not have the psychic opportunity to confront the disaster that negatively impacts the emotional effect through the sense of resignation and despair Thus leading to poor mental health such as PTSD. The prevalence of PTSD reported on several victims of the earthquake in the aftermath of the disaster victims of the Earth Kashmir in 2005 is $33.4 \%$ to $56.7 \%$. As for post-earthquake, it was reported that the incidence of PTSD was $10 \%$ to $47.3 \%$. Up to 10 years after the Wenchuan earthquake was still found PTSD figures in teenagers aged eight years living in the affected area of the earthquake as much as $1.9 \%$ to $2.7 \%$. It provides warnings that children and adolescents need special attention to the impact of long-term earthquakes [20, 21]. 
So that natural earthquake disasters can increase the PTSD figure in adolescents and inflict trauma that has a profound impact on the quality of life $[19,21]$. Table 2 shows the average quality of life of boarders students was higher than public students after an earthquake disaster. Statistical analysis showed that P-value was smaller than $\alpha 0.05$, so it is stated that there is a significant difference between the quality of life of boarders students and public students. Table 3 shows that three $P$ values are smaller than $\alpha 0.05$ in the dimensions of Feeling towards yourself, Friends and school environment. It shows only those dimensions that affect the difference in the quality of life for boarders and public student's post-earthquake disaster.

Table 2. Quality of life of boarders and public students

\begin{tabular}{lccc}
\hline \multicolumn{1}{c}{ Group } & \multicolumn{2}{c}{ Quality of life } & $P$-value \\
& Good & Poor & \\
\hline Boarding school & 27 & 18 & $\mathrm{P}=0.008$ \\
Public school & 17 & 23 & \\
\hline
\end{tabular}

Table 3. Analysis results of each quality of life dimension

\begin{tabular}{lccc}
\hline \multicolumn{1}{c}{ Variable } & OR & $95 \%$ CI & $P$-value \\
\hline Physical activity and health & 0.228 & $0.017-3.058$ & $\mathrm{P}=0.265$ \\
Feeling towards yourself & 0.002 & $0.000-0.050$ & $\mathrm{P}=0.000$ \\
Family and Leisure & 0.131 & $0.009-1.859$ & $\mathrm{P}=0.133$ \\
Friends & 0.017 & $0.001-0.453$ & $\mathrm{P}=0.015$ \\
Schools environment & 0.020 & $0.001-0.509$ & $\mathrm{P}=0.018$ \\
\hline
\end{tabular}

Differences in the quality of life of boarders and public students after the earthquake disaster can also be caused by peer support factors, family and environment [22]. Childhood to adolescence still needs attention and support to achieve the maturity of physical, psychic, and social development. Support and attention not only they need from family but can also from peers and the school environment. Because, the role of the school is not only responsible for students' academic development, but also the development of social students [13].

The school environment becomes the environment that students consider as new families in the social and become one of the defining factors of the quality of life. Quality of life is interpreted as a state of prosperity that is generally and persistent to be identified through positive experiences and produce a sense of happiness, serenity, and contentment [23, 24]. These experiences can be found in both family, environment, and school. Students who live in dormitories at the same school as students living with the family have a lower quality of life than the students who live with their families. It strengthens the opinion that says the closer to a person with his family, the quality of his life is increased [13].

This research shows the quality of life of boarders students higher than public students post-earthquake disaster in North Lombok. This distinction is not caused by damaged buildings and post-earthquake learning facilities because buildings and facilities in boarding schools and public schools have the same damage so that all students undergo a learning process in the tent emergency. Even boarders students live together in emergency tents and away from families.

Based on the statistic result, the difference in the quality of life is caused by Feeling support to themselves, support factor of friends and school environment. The environment in boarding schools not only pay attention to the environment physically but more toward the goal-practice and religious values [25]. The results of this research in accordance with [13] Stating that students live in dormitories have improved quality of life than those not in dormitories. This situation shows that educational institutions with a good dorm environment will be able to improve the quality of life of students learning and living. In the boarding school, the formal learning environment is the number two learning media after social learning and character building by embedding religious values through educators. Religious values instilled in students in boarding schools have a very important role and contribute directly to find solutions to the various problems and give direction on how one can respond to every ward and conditions faced such as post-earthquake natural disaster conditions [25]. A professor, an expert in the field of religion, states that religion has five foundations that give perceptions to understand each incident in the human environment, among others, belief can be influenced from what is read through the book that is believed and can be influenced by other people they believe and the attitude of responsibility to always care about preserving the environment and nature. So what is conveyed by a Ustaz or Kiyai as a leader in the form of solutions or self-confidence can be the animator of the students in the face of every problem, such as the bio-psycho social and spiritual problems that experienced after natural disasters of earthquakes [25].

Religious values that are implanted and applied in the environment of boarding schools are also trusted and believed by students to be clues to life that give a sense of happiness and surrender to God 
clarifications in each condition and situations occur so that psychologically can reduce the anxiety and stress of students $[25,26]$. This can be the reason for the quality of life of boarders students higher than public students post-earthquake disaster in North Lombok

\section{CONCLUSION}

The difference in the quality of life between boarders students and public students was influenced by the support factor of friends and school environment. The higher quality of life on boarders students in Islamic Boarding School can be influenced by the school environment or the huts that always practiced religious values and the togetherness of their fellow students. The change in the quality of life of students as teenagers after the earthquake disaster is also a challenge to be able always to provide prevention that becomes an important factor in the recovery phase and has a significant impact on long-term mental health.

\section{REFERENCES}

[1] AHA Centre, "Situation Update No. 4 M 6.4 Lombok Earthquake (29 Jul 2018) \& M 7.0 Lombok Earthquake (5 Aug 2018), Indonesia," One Asean Center One Response, 2018.

[2] M. Dwidiyanti, I. Hadi, R. I. Wiguna, and H. E. W. Ningsih, "Description of the Risk of Mental Disorders in Victims of Natural Disasters in Lombok, West Nusa Tenggara (In Bahasa Indonesia)," Holistic Nursing and Health Science, vol. 1, no. 2, pp. 82-91, 2018.

[3] X. Mao, O. W. M. Fung, X. Hu, and A. Y. Loke, "Psychological impacts of disaster on rescue workers: A review of the literature," International Journal of Disaster Risk Reduction, vol. 27, pp. 602-617, 2018.

[4] K. Cui and Z. Han, "Association between disaster experience and quality of life: the mediating role of disaster risk perception," Quality Life Research, vol. 28, no. 2, pp. 509-513, 2019.

[5] F. Pistoia et al., "Post-earthquake distress and development of emotional expertise in young adults," Frontiers in Behavioral Neuroscience, vol. 12, no. 91, pp. 1-8, 2018.

[6] A. Z. Othman, A. Dahlan, and S. Murad, "The Impact of Flood Disaster on Daily Activities and Quality of Life amongst Women Flood Disaster Survivors,” Environment-Behavior Proceedings Journal, vol. 2, no. 6, pp. 395-404, 2017.

[7] W. Tian et al., "Longitudinal study on health-related quality of life among child and adolescent survivors of the 2008 Sichuan earthquake," Quality of Life Research, vol. 22, no. 4, pp. 745-752, 2013.

[8] J. Wen, Y. kang Shi, Y. ping Li, P. Yuan, and F. Wang, "Quality of life, physical diseases, and psychological impairment among survivors 3 years after Wenchuan earthquake: A population based survey," PLoS One, vol. 7, no. 8, pp. 1-7, 2012.

[9] L. U. C. Y. Annang et al., "Photovoice: Assessing the Long-Term Impact of a Disaster on a Communitys Quality of Life," Qualitative Health Research, vol. 26, no. 2, pp. 241-251, 2016.

[10] Instruksi Presiden, "Republic of Indonesia Presidential Instruction Number 5 Year 2018 concerning the Acceleration of Rehabilitation and Reconstruction of Earthquake Disasters in West Lombok Regency, Central Lombok Regency, East Lombok Regency, Maratam City, and Affected Areas in Nusa Bali Province (In Bahasa Indonesia)," 2018.

[11] S. Rachma Marcillia and R. Anisza Ratnasari, "Understanding Resident' Activity System-Improving Quality Life: a Case Study of Dome Post Disaster Settlement in Ngelepen Sleman, Yogyakarta," Dimensi-Journal of Architecture and Built Environment, vol. 43, no. 2, pp. 137-142, 2016.

[12] E. J. Johnson and C. A. S. Boodram, "Health, well-being and quality of life of community members displaced after an industrial disaster in Trinidad," Journal of Public Health, vol. 25, no. 1, pp. 69-74, 2017.

[13] Ö. Yaşam and K. Karşılaştırılması, "Comparing the quality of life for boarders and day students at the regional boarding schools in Giresun,” Turk Journal of Public Health, vol. 12, no. 1, pp. 42-50, 2014.

[14] A. H. Berman, B. Liu, S. Ullman, I. Jadbäck, and K. Engström, "Children's quality of life based on the KIDSCREEN27: Child self-report, parent ratings and child-parent agreement in a Swedish random population sample," PLoS One, vol. 11, no. 3, pp. 1-15, 2016.

[15] The Kidscreen Group Europe, "The KIDSCREEN questionnaires: Quality of life questionnaires for children and adolescents," Pabst Science Publisher, 2006.

[16] D. A. Hasibuan, R. Rahmatika, and R. A. Listiyandini, "The Role of Being grateful for Quality of Life related to Health in Adolescents (In Bahasa Indonesia)," in Prossiding Seminar Nasional 2018 Fakultas Psikologi UNDIP, pp. 50-66, 2018.

[17] M. Höfler, "Psychological Resilience Building in Disaster Risk Reduction: Contributions from Adult Education," International Journal of Disaster Risk Science, vol. 5, no. 1, pp. 33-40, 2014. 
[18] W. Tang, Y. Lu, and J. Xu, "Post-traumatic stress disorder, anxiety and depression symptoms among adolescent earthquake victims : comorbidity and associated sleep-disturbing factors," Social Psychiatry and Psychiatric Epidemiology, vol. 53, no. 11, pp. 1241-1251, 2018.

[19] M. R. G. Brown et al., "After the Fort McMurray wildfire there are significant increases in mental health symptoms in grade 7-12 students compared to controls," BMC Psychiatry, vol. 19, no. 18, pp. 1-11, 2019.

[20] E. Nygaard, A. Hussain, J. Siqveland, and T. Heir, "General self-efficacy and posttraumatic stress after a natural disaster: A longitudinal study,” BMC Psychology, vol. 4, no. 15, pp. 1-11, 2016.

[21] Z. Wang and J. Xu, "Association between Resilience and Quality of life in Wenchuan Earthquake Shidu parents : The Mediating Role of Social Support," Community Mental Health Journal, vol. 53, no. 7, pp. 859-863, 2017.

[22] S. H. Lee, E. J. Kim, J. Noh, and J. Chae, "Factors Associated with Post-traumatic Stress Symptoms in Students Who Survived 20 Months after the Sewol Ferry Disaster in Korea," Journal Korean Med. Science, vol. 33, no. 11, pp. 1-9, 2018.

[23] J. Siqveland, E. Nygaard, A. Hussain, R. G. Tedeschi, and T. Heir, "Posttraumatic growth, depression and posttraumatic stress in relation to quality of life in tsunami survivors: A longitudinal study," Health and Quality of Life Outcomes, vol. 13, no. 18 , pp. 1-8, 2015.

[24] T. Hu, S. Xu, and W. Liu, "A senior high school-based survey on the long-term impact of the Wenchuan earthquake on survivors' quality of life: PTSD as a mediator," Psychiatry Research, vol. 270, pp. 310-316, 2018.

[25] D. Dirosahislamiyah, "The Role of Islamic Boarding School as Socialization Agent of Ecological Values (A Case Study in Salaf-Modern Islamic Boarding School)," Wacana, vol. 20, no. 4, 2017.

[26] M. Elliott and M. J. Doane, "Religion in Adolescents," Encyclopedia of Quality of Life and Well-Being Research, no. 7 , pp. 5469-5469, 2014 